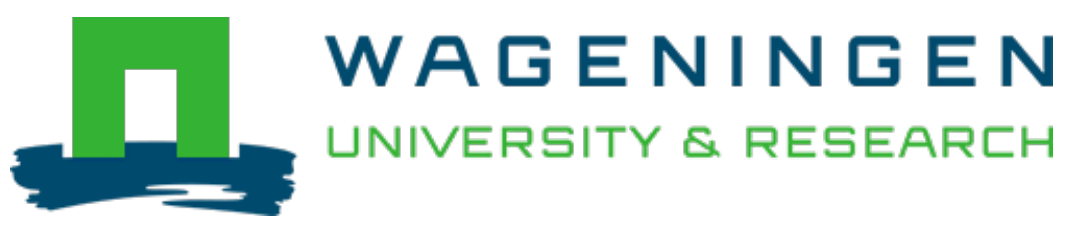

\title{
Herders and livestock professionals' experiences and perceptions on developments and challenges in yak farming in Bhutan
}

\author{
Animal Production Science \\ Dorji, Nedup; Derks, Marjolein; Dorji, Phub; Groot Koerkamp, Peter W.G.; Bokkers, Eddie A.M. \\ https://doi.org/10.1071/AN19090
}

This article is made publicly available in the institutional repository of Wageningen University and Research, under the terms of article $25 \mathrm{fa}$ of the Dutch Copyright Act, also known as the Amendment Taverne. This has been done with explicit consent by the author.

Article 25 fa states that the author of a short scientific work funded either wholly or partially by Dutch public funds is entitled to make that work publicly available for no consideration following a reasonable period of time after the work was first published, provided that clear reference is made to the source of the first publication of the work.

This publication is distributed under The Association of Universities in the Netherlands (VSNU) 'Article $25 \mathrm{fa}$ implementation' project. In this project research outputs of researchers employed by Dutch Universities that comply with the legal requirements of Article $25 \mathrm{fa}$ of the Dutch Copyright Act are distributed online and free of cost or other barriers in institutional repositories. Research outputs are distributed six months after their first online publication in the original published version and with proper attribution to the source of the original publication.

You are permitted to download and use the publication for personal purposes. All rights remain with the author(s) and / or copyright owner(s) of this work. Any use of the publication or parts of it other than authorised under article $25 \mathrm{fa}$ of the Dutch Copyright act is prohibited. Wageningen University \& Research and the author(s) of this publication shall not be held responsible or liable for any damages resulting from your (re)use of this publication.

For questions regarding the public availability of this article please contact openscience.library@,wur.nl 


\title{
Herders and livestock professionals' experiences and perceptions on developments and challenges in yak farming in Bhutan
}

\author{
Nedup Dorji (D) A,B,C,D, Marjolein Derks ${ }^{\text {A }}$, Phub Dorji ${ }^{\mathrm{C}}$, Peter W. G. Groot Koerkamp ${ }^{\mathrm{A}}$ \\ and Eddie A. M. Bokkers ${ }^{\mathrm{B}}$ \\ AFarm Technology Group, Wageningen University and Research, PO Box 16, Wageningen, 6700, \\ the Netherlands. \\ ${ }^{\mathrm{B}}$ Animal Production Systems Group, Wageningen University and Research, PO Box 338, Wageningen, \\ $6700 \mathrm{AH}$, the Netherlands. \\ ${ }^{\mathrm{C}}$ Department of Animal Science, College of Natural Resources, Royal University of Bhutan, Lobesa, Bhutan. \\ DCorresponding author. Email: nedup@cnr.edu.bt; nedup.dorji@wur.nl
}

\begin{abstract}
Context. The yak-based transhumant system is influenced by socioeconomic developments, regulations and environmental changes. Little is known about the impact of this on yak farming practices among different regions in Bhutan.

Aim and methods. The experienced changes in yak farming practices over the years and perceptions on developments were assessed through interviews with yak herders in three regions (west, $n=22$; central, $n=20$; east, $n=25$ ) and with livestock extensionists $(n=28)$.

Key results. At present, forage shortage in the rangeland, yak mortality mainly due to (endangered) wild predators and, to a lesser extent, labour availability are the main concerns in all yak farming regions. These concerns have increased due to socioeconomic developments (e.g. education and other sources of income) and strong conservation policy, which affects the living environment of the yaks. Overall, the market to sell yak products and livestock extension services has improved, but forage shortage and yak mortality has increased over the years. However, some factors causing forage shortage are more specific to certain regions, e.g. competition with the horse population (west), cattle and cattle-yak hybrids (east), cordyceps collection (west and central) and prohibited burning of rangelands (central and east). Family labour available to herd yaks has slightly decreased, and the number of young family members (successors) to take over yak farming has decreased over the years.

Conclusions. On the basis of the experiences and perceptions of yak herders and extensionists, we conclude that increasing forage shortage in the rangelands, decreasing numbers of successors, and increasing yak predation by wild animals are the major threats to yak farming.

Implications. This study demonstrates that yak farming in Bhutan experiences an increasing pressure to sustain. Differences between regions make clear that a one blanket-policy will not be effective to preserve yak farming for the future.
\end{abstract}

Additional keywords: welfare, policy.

Received 14 February 2019, accepted 29 May 2020, published online 7 July 2020

\section{Introduction}

Highland pastoralists in the northern region of Bhutan highly depend on their yaks because these animals provide several products such as food and fur and are also used as pack animals. The arid and semiarid environment has one of the harshest climatic conditions, yet pastoralists have capitalised the available natural resources there. In Bhutan, yak-based communities are considered transhumant pastoralists because they practice seasonal migration between alpine and cool-temperate zones in response to forage availability (Gyamtsho 2000), while the families remain in a permanent settlement (Allen et al. 2011). Yak-based communities are important for Bhutan because they preserve a rich culture and tradition, which is one of the four main pillars of the Bhutanese development philosophy. Yak-based systems have an effect on the landscape and ecosystem (McVeigh 2004). For instance, grazing and trampling by animals control grass species diversity in the rangelands, while allowing young plants to grow and develop. Nevertheless, 30 households leave yak farming every year (Phuntsho and Dorji 2016).

Yak-based communities are affected by socioeconomic developments (e.g. access to education, development of a dairy farm) and regulations (e.g. Forest and Nature Conservation Act 1995). Education results in literate youth who might view yak farming as an old-fashioned way of supporting livelihood, and they may seek better opportunities 
and scope in towns (Wangdi 2016). Additionally, access to other livelihoods might strongly affect the interest in yak farming. For instance, both young and adults of many yakbased families of central and western regions collect cordyceps (Cordyceps sinensis, a mushroom for which medicinal effects are assumed and which is mainly sold to Chinese people) on the rangelands from May to July (Wangchuk and Wangdi 2015). Both developments might lead to a labour shortage for herding yaks and selling yak products, which might affect viability of yak-based communities.

There are three important factors related to policy that are assumed to have influenced decisions of families to continue yak farming. The first is the Forest Act established in 1969, which prohibits the traditional method (burning) of rejuvenating rangelands and controlling shrub proliferation, thereby negatively affecting forage availability for the yak. Second, most rangelands at a high altitude are within protected areas (national parks and wildlife sanctuaries), which also are home to wild endangered and protected predators such as the tiger (Panthera tigris), snow leopard (Panthera uncia), bear (Ursus thibetanus) and Asiatic wild dog (Cuon alpinus), and may lead to increased yak predation and human-wildlife conflicts. Third, the Land Act established in 2007 states that the rangelands will be nationalised and leased back to yak herders and livestock farmers by 2017. This may have led or may lead to conflicts among different rangeland users (yak herders, horse farmers, cattle farmers). To what extent these policies affect yak farming practices has never been studied from the perspective of herders and livestock professionals.

Since Bhutan is a mountainous country with large regional differences in the capacity to adapt to challenges, development might differ among regions. Regions in Bhutan have been, for a long time, isolated from each other due to the mountainous landscape, low population density and poor infrastructure (Derville and Bonnemaire 2010), and also more recent developments differ among regions, such as establishment of farmer shops and dairy farmer groups in the central region. Therefore, the present study assesses the past experiences and current perceptions of yak herders and livestock professionals from different regions on challenges and developments in yak farming.

\section{Materials and methods}

\section{Study sites}

Bhutan has 10 districts where yak farming is operated (DoL 2008). These districts can be stratified in a western, central and eastern regions. These three regions were chosen because they differ substantially in culture and traditions, which affect yak farming practices (Wangchuk et al. 2013a), specific types of yak products produced, the practice of cattle-yak hybridisation, source of income, and agricultural land (Derville and Bonnemaire 2010). Within a district, a geog (block) functions as the local administrative unit and contains several villages.

For the present study, we selected one representative block per region. Laya (western region), Saephu (central region) and Merag (eastern region) are all located more than $3000 \mathrm{~m}$ above sea level and safely reachable within 1 day of traveling. Selected blocks were representative of each region, and certain characteristics were specific for each region. (1) In the western region, only purebred yaks are kept and milk is processed to butter and cheese (dried and fresh). Besides, family members are involved in cordyceps collection and tourism. They own small areas of land in the village and they cultivate buckwheat, barley, mustard and vegetables. (2) In the central region, mainly purebred yaks and a few cattle-yak hybrids are kept and milk is processed to butter and cheese (dried and fresh). Family members are involved in cordyceps collection. They mainly grow potatoes and vegetables to sell. (3) In the eastern region, approximately an equal number of purebred yaks and cattle-yak hybrids are kept, while milk is processed to butter and fermented cheese. Herders trade yak products with the local community as well as with people in Arunachal Pradesh, India. They are not involved in cordyceps collection. Generally, they do not grow crops. A detailed description of the differences among the regions is given by Derville and Bonnemaire (2010). In the results, regions are used instead of the name of yak farming blocks: western for Laya, central for Saephu, and eastern for Merag.

\section{Data collection}

Data were collected from herders by conducting face-to-face interviews, and from livestock professionals (local livestock extensionists, yak researchers) who were working with yakbased communities through face-to-face interviews and a selfadministered computer questionnaire sent via email. The two data-collection methods were used for livestock professionals because the respondents were working in different areas, and they were not all accessible in person. Data from livestock professionals were collected to verify and supplement the information on the current situation of yak farming practices obtained through the interviews with the herders.

A verbal consent was obtained from the respondents to participate in the interview, and to audio-record the interview. The purpose of the study was briefly explained to the respondents and they were assured that the participation in the study was voluntary and their identity would be protected (Corti et al. 2000). For example, when a livestock extensionist and local health worker escorted the investigator to a yak campsite or house, the interview was conducted in a private setting to ensure a safe environment for interviewee and interviewer. All interviews were conducted in the Bhutanese national language (western and central regions) and the local dialect called sharchopkha (eastern region). Hence, the questions constructed in English were translated to the national language. Each translated question was verified by a qualified translator. Because the interviewer was a native speaker of the local dialect, the translated questions were used and, where needed, adapted to the local dialect to interview the herders in the eastern region.

The questionnaire was tested with three yak herders located in the Tsento block (which was not selected for the study) to check the level and length of questions and questionnaire. Similarly, two Bachelor of Science students studying Animal Science at the College of Natural Resources, who worked with yak-based communities, were used to test the questionnaire on livestock professionals. The questionnaire was revised and adapted after testing, and the final version was then used to interview the yak herders. 


\section{Interview of yak herders}

A purposeful sampling method was used to identify and select yak herders for an interview. In the first meeting with the livestock extensionist and the local health worker, yak herders to be visited were identified on the basis of current proximity of the yak herds to the permanent village, and the number and location of the yaks. Sixty-seven yak herders (Laya, 22; Saephu, 20; Merag, 25) from 16 villages (Laya, 5; Saephu, 8; Merag, 3) were interviewed. The interview was constructed as a semi-structured questionnaire, and it consisted of the following four main topics:

(1) Basic respondent information (age, sex, education level, years of yak herding), and source of income and livelihood for current and past situations (based on the number of years of herding experience).

(2) Practices related to yak herd migration (start date of migration between the rangelands, migration route, which family member migrates with yak herds) for current and past situation.

(3) Current yak farming practices to sell yak products, market situation for yak products, labour situation, forage availability, yak mortality, and coping strategies to challenges.

(4) The opinion of yak herders on the level of changes experienced over the years on the market for selling yak products, labour availability, forage availability, mortality, access to veterinary and health services, and prevalence of diseases and parasites.

\section{Interview of livestock professionals}

Two local livestock extensionists from two regions were interviewed face to face during the visit. In addition, the questionnaire was sent to 26 other local livestock extensionists working with yak-based communities at present or who had worked until a maximum of 12 months ago, and to six yak researchers in Bhutan. Twenty-four livestock extensionists and two yak researchers returned the questionnaire. This semi-structured questionnaire included the following three sections:

(1) Respondent basic information (sex, education level, number of years working with yak-based communities).

(2) The opinion of livestock professionals on the current yak farming practices (market situation for yak products, labour situation, forage availability and yak mortality).

(3) The opinion of livestock professionals on the level of changes that yak herders might experience on the market situation for yak products, labour situation, forage availability and mortality, access to veterinary and health services, and prevalence of diseases and parasites.

\section{Interview of non-yak farmers}

Non-yak farmers (farmers who did not keep yaks) were interviewed face to face. A snowball method was used to reach the target farmers through a respondents' network (Heckathorn and Cameron 2017) because there was no prior information on non-yak farmers. Twenty-six non-yak farmers (Laya, 7; Merag, 10; Saephu, 9) from the same villages visited for yak herds were interviewed about previous involvement in yak farming and the reason for abandoning yak farming.

\section{Data analyses}

Data were entered into Excel and then analysed in R Studio (R Core Team, 2017). Two-sided Fisher exact tests were performed to check whether the current situation of livelihood, yak products for sale, yak product customers, and money spent from sale of yak products differed from those in the past. A Kruskal-Wallis test was performed to compare herd size and mortality among the regions.

Herder characteristics (age, gender, education, yak herd size and region) were treated as explanatory variables in a logistic regression. The education level was coded as 'attended school' and 'did not attend school'. A binomial logistic regression model was used to assess the association between the explanatory variables and the experience on the problem to sell yak products, labour shortage, forage shortage and yak mortality. A Hosmer-Lemeshow goodness-of-fit test was used to check whether the explanatory variables were correctly specified in the model by using the packages 'generalhoslem' in R. Also, the model accuracy was evaluated by calculating a confusion matrix. A Hosmer-Lemeshow test results $(P>0.05)$ and the confusion matrix $(75 \%)$ indicated no evidence of poor model fit.

Furthermore, Mann-Whitney $U$ tests were performed to check whether the view of livestock professionals on the cause and developments in yak farming practices differed from the experience of yak herders.

\section{Results}

The results are presented as an overview of yak farming practices in Bhutan; however, distinctive features in different yak farming regions are also mentioned.

\section{Respondent characteristics}

Table 1 shows some basic characteristics of the respondents. The yak herders were mainly male in the eastern region, and female in the western and central regions. Most of them were illiterate and the average age (mean \pm s.e.m.) of the herders was $39.7 \pm 3.1$ years for western, $41.9 \pm 2.8$ years for central and $49.1 \pm 3.1$ years for the eastern region. More than half of the herders had been herding yaks for more than 15 years. The average yak herd size was $49.8 \pm 8.6$ for western, $47.4 \pm 4.7$ for central and $54.6 \pm 5.8$ for the eastern region. The livestock professionals were mainly male, literate and had more than 6 years of working experience with yak-based communities.

\section{Yak-based transhumant livelihoods}

Yak-based communities depended on more than one source of livelihood (Table 2). In the western and central regions, yak farming has become less important for livelihood over the years, while cordyceps collection has become more important $(P<0.05)$. Tourism was also a source of livelihood in the western region.

Although there were different livelihoods, yak farming was the preferred choice of livelihood in all three regions. The 
herders indicated that yak farming was a reliable source of livelihood because yaks have multiple functions (provide food and fur, draft power, insurance, cultural identity) and yaks

Table 1. Respondent characteristics (\%)

\begin{tabular}{lcccc}
\hline Characteristic & \multicolumn{3}{c}{ Yak herders } \\
& $\begin{array}{c}\text { Western } \\
(n=22)\end{array}$ & $\begin{array}{c}\text { Central } \\
(n=20)\end{array}$ & $\begin{array}{c}\text { Eastern } \\
(n=25)\end{array}$ & $\begin{array}{c}\text { Livestock } \\
\text { professionals } \\
(n=28)\end{array}$ \\
\hline Gender & & & & \\
$\quad$ Male & 34 & 40 & 76 & 85 \\
$\quad$ Female & 56 & 60 & 24 & 14 \\
Education & & & & \\
$\quad$ Illiterate & 73 & 80 & 88 & \\
$\quad$ Primary school & 19 & 20 & 0 & \\
$\quad$ Non-formal education & 9 & 0 & 12 & \\
Diploma & & & & 77 \\
$\quad$ Undergraduate & & & & 15 \\
$\quad$ Others & & & & 8 \\
Yak herding experience & 14 & 20 & 12 & 41 \\
$\quad \leq 5$ years & 18 & 0 & 0 & 37 \\
6 to $\leq 10$ years & 9 & 25 & 12 & 7 \\
11 to $\leq 15$ years & 59 & 55 & 76 & 15 \\
$\quad 16$ years & & & & \\
\hline
\end{tabular}

have been reared for centuries, while cordyceps collection is seen as unsustainable due to overexploitation of the resources. The preferred choice of livelihood for yak herders was not associated with the number of years of yak herding $(P>0.05)$. More than $25 \%$ of the herders in the western and central regions preferred cordyceps collection as their livelihood because it generated high revenues. Likewise, farming cattle-yak hybrids was the preferred livelihood source for a large group of herders in the eastern region, because these hybrids were more productive than were purebred yaks (Table 2).

\section{Sales of yak products and market situation}

Small-sized dry cheese $(4 \times 1.5 \times 1 \mathrm{~cm})$ was the most valuable yak product to sell in the western and in the central regions (Table 3), and this dry cheese had become more popular to sell than in the past. In contrast, meat used to be the most important product for sale in the past, but its popularity has declined over the years. Herders mentioned that the slaughtering of yaks began to decline $\sim 10-15$ years ago because of increasing religious sentiment among yak herders. When a herder slaughters a yak, a herder can experience societal pressure and is often stigmatised. Overall, the most important yak

Table 2. The most important source of livelihood at present and in the past years, and preferred choice of livelihood in three yak farming regions $(\%)$

\begin{tabular}{|c|c|c|c|c|c|c|}
\hline \multirow[t]{2}{*}{ Livelihood activity } & \multicolumn{2}{|c|}{ Western region $(n=22)$} & \multicolumn{2}{|c|}{ Central region $(n=20)$} & \multicolumn{2}{|c|}{ Eastern region $(n=25)$} \\
\hline & At present & Before & At present & Before & At present & Before \\
\hline \multicolumn{7}{|c|}{ Main source of livelihood to your family } \\
\hline Yak farming & 26 & 86 & 19 & 81 & 68 & 50 \\
\hline Cordyceps & 52 & 5 & 81 & 14 & 0 & 0 \\
\hline Cattle-yak hybrid farming & 0 & 0 & 0 & 0 & 24 & 50 \\
\hline Other (horse, shop, sheep) & 22 & 9 & 0 & 5 & 8 & 0 \\
\hline \multicolumn{7}{|c|}{ Preferred choice of livelihood } \\
\hline Yak farming & 65 & & 71 & & 54 & \\
\hline Cordyceps & 26 & & 29 & & 0 & \\
\hline Cattle-yak hybrid farming & 0 & & 0 & & 38 & \\
\hline Other (horse, shop) & 9 & & 0 & & 8 & \\
\hline \multicolumn{7}{|c|}{ Reason for the preferred choice of livelihood } \\
\hline Yak farming is reliable source of livelihood & 52 & & 60 & & 47 & \\
\hline Yak farming is tradition and culture & 13 & & 15 & & 7 & \\
\hline $\begin{array}{l}\text { Yak farming is easy compared with } \\
\text { cattle-yak hybrid farming }\end{array}$ & 0 & & 0 & & 13 & \\
\hline Cordyceps fetch high income & 26 & & 30 & & 0 & \\
\hline Cattle-yak hybrids fetch high income & 0 & & 0 & & 38 & \\
\hline Other (easy work) & 9 & & 0 & & 8 & \\
\hline
\end{tabular}

Table 3. The economic most important yak products at present and the past years in three regions (\%)

\begin{tabular}{|c|c|c|c|c|c|c|}
\hline \multirow[t]{2}{*}{ Most important yak product to sell } & \multicolumn{2}{|c|}{ Western region $(n=22)$} & \multicolumn{2}{|c|}{ Central region $(n=20)$} & \multicolumn{2}{|c|}{ Eastern region $(n=25)$} \\
\hline & At present & Before & At present & Before & At present & Before \\
\hline Butter & 21 & 25 & 28 & 23 & 34 & 40 \\
\hline Big-sized dry cheese & 36 & 29 & 12 & 8 & 0 & 0 \\
\hline Small-sized dry cheese & 39 & 14 & 52 & 23 & 0 & 0 \\
\hline Fermented cheese & 0 & 0 & 0 & 0 & 58 & 50 \\
\hline Meat & 4 & 32 & 8 & 46 & 0 & 5 \\
\hline Other (hair, sell live yaks) & 0 & 0 & 0 & 0 & 8 & 5 \\
\hline
\end{tabular}


products produced to sell have changed over the years $(P<0.05)$. These changes in sales of yak products may be explained by a change of customers. In the past, more than half of the herders bartered their yak products with lowland farmers, while, nowadays, citizens in towns are also an important group of customers.

The money earned through selling yak products was said to be mainly spent on daily household requirements, investments in yak farming (purchase wheat or maize flour, oil, salt), purchase of clothes, and sending children to school (Table 4). Herders (east, $27 \%$; central, 35\%) answered that the money invested in yak farming had increased compared with the past, while, in the western region, the money invested had not changed. About $44 \%$ of the herders spent at least $40 \%$ of the total revenue from selling yaks and yak products in yak farming.

None of the age, gender, level of education, yak herd size or region was significantly related to the herder's experience regarding ease of selling yak products $(P>0.05)$. However, differences were observed in the herders' experience regarding ease of selling yak products and the regions $(P<0.05)$.

More than half of the herders interviewed $(76 \%)$ responded that they were able to sell their yak products, which was confirmed by $68 \%$ of the livestock professionals $(P>0.05)$. However, some herders (west, 36\%; central, 30\%; east, $8 \%$ ) indicated they had experienced problems mainly in selling yak butter, because of competition with butter from dairy cows and from cheap imported margarine from India. For example, the cheap margarine has replaced often the use of yak butter in making ritual cakes and burning butter lamps during religious festivals in the western and central region. Other reasons that were mentioned were the unhealthy image of yak butter and transport problems (poor road conditions, long distance). For these reasons, some herders of the central and western regions perceived that the market for selling yak products had deteriorated over the years. Those herders who were not able to sell their yak butter, often offered it to illuminate the butter lamps in the temples and monasteries.

\section{Yak herd migration}

Except for $12 \%$ of the herders in the eastern region that did not migrate, herders practiced moving from cool temperate (winter

Table 4. Customers of yak products and spending of money earned by yak products at present and the past years

\begin{tabular}{lccc}
\hline Parameter & $\begin{array}{c}\text { At present } \\
(\%)\end{array}$ & $\begin{array}{c}\text { Past } \\
\text { years } \\
(\%)\end{array}$ & $\begin{array}{c}\text { Fisher } \\
\text { exact } \\
\text { test }\end{array}$ \\
\hline \multicolumn{4}{c}{ Most common customers for yak products } \\
Lowland farmers & 44 & 72 & $P<0.05$ \\
Citizens in towns & 30 & 8 & \\
Citizens of India & 4 & 9 & \\
Others (yak farmers, non-yak farmers) & 22 & 11 & \\
$\quad$ Most common usage for money earned from sales of yak products \\
Daily household requirements & 61 & 75 & $P>0.05$ \\
Yak farming & 32 & 23 & \\
Purchasing clothes & 1 & 2 & \\
Education of children & 6 & 0 & \\
\hline
\end{tabular}

campsite) to subalpine and alpine zones (summer campsite) to take advantage of forage availability on the basis of seasons. Herders still followed the traditional migration routes.

Most of the herders (95\%) began to migrate from summer to winter rangeland between August and October. Likewise, $80 \%$ of the herders migrated from winter to summer rangeland between April and May. In the eastern region, the start date of migration between rangelands has not changed from that in the past, whereas in the western (14\%) and central (75\%) regions, migration started earlier from winter to summer rangelands because of cordyceps collection. Herders indicated that yaks must compete with horses on the rangelands where cordyceps is collected. Similarly, herders of the western (9\%) and central $(20 \%)$ regions said that they migrated to winter rangeland earlier than they did in the past because of forage shortage (western and central region) and unpredictable weather (central region).

\section{Labour situation}

Difference in gender involvement with yak herding was observed in different regions. (1) In the eastern region, equal proportions of herders were male (48\%) or partnerships between female and male (48\%), and the rest were herded by more than two persons (4\%). (2) In the central region, about half of the herders were female $(55 \%)$ or partnerships between female and male (40\%), and the rest were herded by more than two persons (5\%). (3) In the western region, a high proportion of herders was female $(77 \%)$, followed by partnerships between female and male $(23 \%)$. Although most of the herders (west, 77\%; central, 70\%) said that two people were involved during herd migration, less than half of the herders mentioned that two people were involved in yak herding (west, 23\%; central, 40\%). When two people were involved with yak herding, they usually had defined roles and responsibilities. One person looked after the yak calves, performed milking, processed the milk to butter and cheese, and took care of shearing and household chores. The other person herded the yaks (drive and gather) and collected forage and firewood. When one person was herding yaks, a part-time herder also contributed to yak herding. A part-time herder returned to the village to attend meetings, looked after children and elderly people, brought food items to yak herds and collected the yak products.

There was no significant association between the profile characteristics of herders and the experienced labour shortage to herd yaks $(P>0.05)$. The herders (west, $77 \%$; central, $55 \%$; east, $76 \%$ ) had the opinion that family labour was currently sufficient to maintain yak herding. In contrast, most livestock professionals $(89 \%)$ believed that the yak farming families experience labour shortage to herd yaks $(P<0.05)$.

Herders who experienced labour shortage $(n=20)$ and livestock professionals $(n=25)$ agreed that the access to modern education accounted for labour shortage in yak herding to a large extent. Nowadays, most children of yakbased family were attending school, and the literate youth (even if unemployed) were often not willing to herd yaks. Seven herders and 23 livestock professionals expressed the view that young people leave and move to towns. Currently, six herders thought that they were relatively old ( $>65$ years) 
which caused the labour shortage for herding yaks. Seven herders believed that the involvement of family members in cordyceps collection, tourism activities (west, 2) and diversification of livestock farming (east, 2) contributed to family labour shortages, which was in contrast with the view of livestock professionals (cordyceps collection, 16; tourism activities 15; diversification of livestock farming, 21). Moreover, some herders (west, 3; central, 4; east, 3) thought that the increased size of their own herd size caused labour shortage.

Herders who experienced labour shortage solved this problem by selling yaks, seeking assistance from relatives, or collaborating with neighbouring yak herders to combine their yaks (Fig. 1). Some herders (west, 4; central, 1; east, 1) did not do anything in response to their labour shortage.

\section{Forage}

Herders responded that they used to own rangeland (49\%), and they used governmental and communal rangelands (24\%), and rangelands owned by monastic bodies, cattle-yak hybrids farmers, or other yak farmers $(27 \%)$. Those herders who used rangeland owned by others paid a fee either in cash or with yak products. Depending on the size and quality of the rangeland, herders of the western and central region paid-inkind $15-60 \mathrm{~kg}$ butter per rangeland per year (representing a value of US\$ 4.5-7.5 per $\mathrm{kg}$ butter;1 US\$ = Bhutanese Ngultrum 67) and in the eastern region they paid-in-kind 2-20 kg butter per rangeland per year to rangeland owners. The Land Act 2007 dissolved this system of rangeland arrangement as the rangeland was to be nationalised. However, the Land Act 2007 had not been implemented yet when the study areas were visited.

There was no significant association between herder characteristics and the experienced forage shortage, except for age $(\beta=-0.15, P=0.03$, odd ratio $=0.86,95 \% \mathrm{CI}=$ 0.72-0.96). Currently, most herders (west, 91\%; central,
$100 \%$; east, $88 \%$ ) experienced forage shortage, which was confirmed by the view of $96 \%$ of the livestock professionals $(P>0.05)$. In general, both herders and livestock professionals believed that the prohibition of the traditional method of rejuvenating rangelands was the main cause for forage shortage (Table 5). Herders were aware that burning bushes and shrubs in the rangeland was prohibited. More than half of the respondents (herders and livestock professionals) believed that the increase in yak population in the community, and competition with cattle, cattle hybrids and horses were contributors to the forage shortage in yak farming regions (Table 5).

Herders and livestock professionals disagreed on some aspects causing forage shortage (Table 5). Only a small part of the herders believed that an increase in family yak herd size, rangeland division among family members, less snow coverage on the rangeland and lease of rangeland attributed to forage shortage. In contrast, more than half of the livestock professionals thought that those factors (increased family yak herd size, less snow coverage on the rangeland, lease of rangeland) resulted in forage shortage. However, livestock professionals agreed with herders of a specific region (Appendix 1) that the rangeland division among the family members (east herders, 76\%; livestock professionals, 63\%) and less rain (west herder, 64\%; livestock professionals, 63\%) caused forage shortage. However, this traditional method of subdividing rangeland among the family members will be dissolved when the Land Act 2007 is implemented. In the western region, $\sim 91 \%$ of the herders stated that the increasing horse population related to cordyceps collection and tourism had caused forage shortage. Also, some herders (west, 55\%; central, 60\%) considered that cordyceps collection contributed to areas of bare soil susceptible to erosion. In addition, $\sim 40 \%$ (west) and $65 \%$ (central) of the herders believed that the increased wild herbivores (takin, Budorcas taxicolor; blue sheep, Pseudois nayaur) caused forage shortage. Equal proportions of the herders in the western

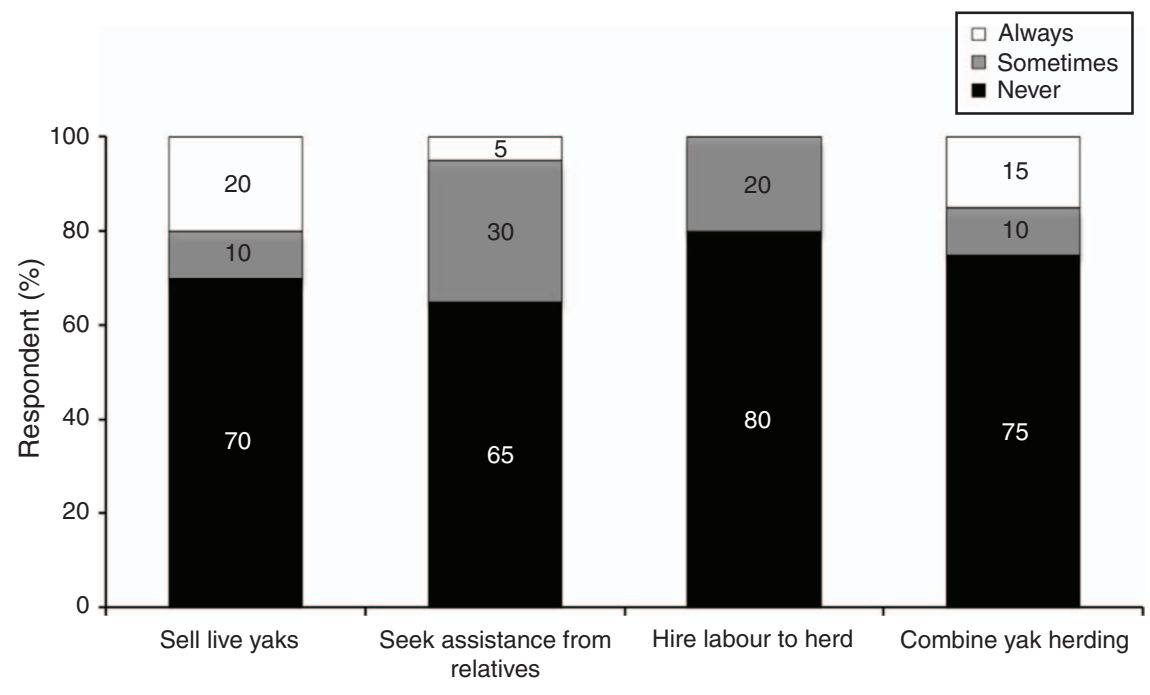

Frequency of response to labour shortage

Fig. 1. Response to labour shortage by yak herders who experience labour shortage (\%). 
Table 5. Yak herders' $(n=62)$ experience and livestock professionals' $(n=27)$ view on aspects affecting forage availability (see for details per region Appendix 1)

$P$-values are given (Mann-Whitney $U$ test)

\begin{tabular}{|c|c|c|c|c|c|c|}
\hline \multirow[t]{2}{*}{ Respondent group } & \multicolumn{5}{|c|}{ Level of effect on forage availability (\%) } & \multirow[t]{2}{*}{$P$-value } \\
\hline & Not at all & Small extent & Moderate extent & Large extent & Don't know & \\
\hline \multicolumn{7}{|c|}{ Increase family yak herd size } \\
\hline Yak herders & 69 & 12 & 13 & 5 & 1 & 0.016 \\
\hline Livestock professionals & 37 & 30 & 11 & 18 & 4 & \\
\hline \multicolumn{7}{|c|}{ Increase community yak herd size } \\
\hline Yak herders & 42 & 10 & 28 & 18 & 2 & 0.261 \\
\hline Livestock professionals & 44 & 30 & 7 & 15 & 4 & \\
\hline \multicolumn{7}{|c|}{ Increase competition with cattle } \\
\hline Yak herders & 42 & 7 & 24 & 22 & 4 & 0.980 \\
\hline Livestock professionals & 19 & 30 & 29 & 15 & 7 & \\
\hline \multicolumn{7}{|c|}{ Increase competition with horse } \\
\hline Yak herders & 42 & 22 & 12 & 24 & 0 & 0.219 \\
\hline Livestock professionals & 22 & 19 & 32 & 22 & 4 & \\
\hline \multicolumn{7}{|c|}{ Rangeland division among family members } \\
\hline Yak herders & 60 & 6 & 3 & 30 & 1 & 0.378 \\
\hline Livestock professionals & 22 & 26 & 26 & 11 & 15 & \\
\hline \multicolumn{7}{|c|}{ Cordyceps collection sites } \\
\hline Yak herders & 64 & 9 & 12 & 14 & 0 & 0.697 \\
\hline Livestock professionals & 48 & 15 & 12 & 11 & 15 & \\
\hline \multicolumn{7}{|c|}{ Prohibited burning of the rangeland } \\
\hline Yak herders & 36 & 7 & 21 & 34 & 2 & 0.651 \\
\hline Livestock professionals & 19 & 23 & 4 & 39 & 15 & \\
\hline \multicolumn{7}{|c|}{ Land Act 2007 (lease rangeland) } \\
\hline Yak herders & 64 & 1 & 3 & 13 & 18 & 0.022 \\
\hline Livestock professionals & 37 & 26 & 19 & 7 & 11 & \\
\hline \multicolumn{7}{|c|}{ Less rainfall } \\
\hline Yak herders $^{\mathrm{A}}$ & 48 & 22 & 16 & 1 & 9 & 0.001 \\
\hline Livestock professionals & 30 & 33 & 8 & 22 & 7 & \\
\hline \multicolumn{7}{|c|}{ Soil erosion } \\
\hline Yak herders & 60 & 17 & 16 & 7 & 0 & 0.204 \\
\hline Livestock professionals & 33 & 19 & 7 & 15 & 26 & \\
\hline \multicolumn{7}{|c|}{ Less snow coverage on the mountains ${ }^{B}$} \\
\hline Yak herders & 51 & 9 & 11 & 4 & 13 & 0.010 \\
\hline Livestock professionals & 26 & 41 & 14 & 15 & 4 & \\
\hline
\end{tabular}

${ }^{\mathrm{A}} 4 \%$ of the herders believed that heavy rainfall in summer caused forage shortage.

${ }^{\mathrm{B}} 12 \%$ of the herders thought that more snow cover on the rangeland caused forage shortage.

region believed that less snow coverage (32\%) and more snow coverage $(32 \%)$ on the rangelands caused forage shortage. Those herders who viewed that less snow coverage on the rangeland caused forage shortage mentioned that grasses and forbes required melt water to grow.

However, the largest contrasts across the regions were found in feeding cattle feed concentrate, supplementary forage, selling yaks, and constructing fences around the rangeland to keep other ruminants away (Fig. 2). During forage shortage, more than half of the herders (west, $86 \%$; central, 75\%) provided cattle concentrate purchased from the towns, to their yaks. Herders of the western (55\%) and central (45\%) regions supplemented their yaks with improved mixed forage (mixture of cocksfoot, rye, and others), and herders also provided supplementary forage such as turnips, radish and others crops (west, 14\%; central, 85\%). In contrast, herders of the eastern region did not provide any supplementary feed and forage, but sold live yaks $(56 \%)$ and made or maintained fences around the rangeland to keep other animals away $(76 \%)$ as a response to forage shortage.

\section{Yak mortality}

Most of the herders (west, 96\%; central, 95\%; east, 84\%) observed yak mortality from September 2016 to October 2017. Herders of the western region observed a higher average number of yak mortalities (15 \pm 2 animals) than did herders of the central (11.6 \pm 1.7 animals $)$ and the eastern $(5.1 \pm 0.7$ animals $)$ regions $(P<0.05)$. 

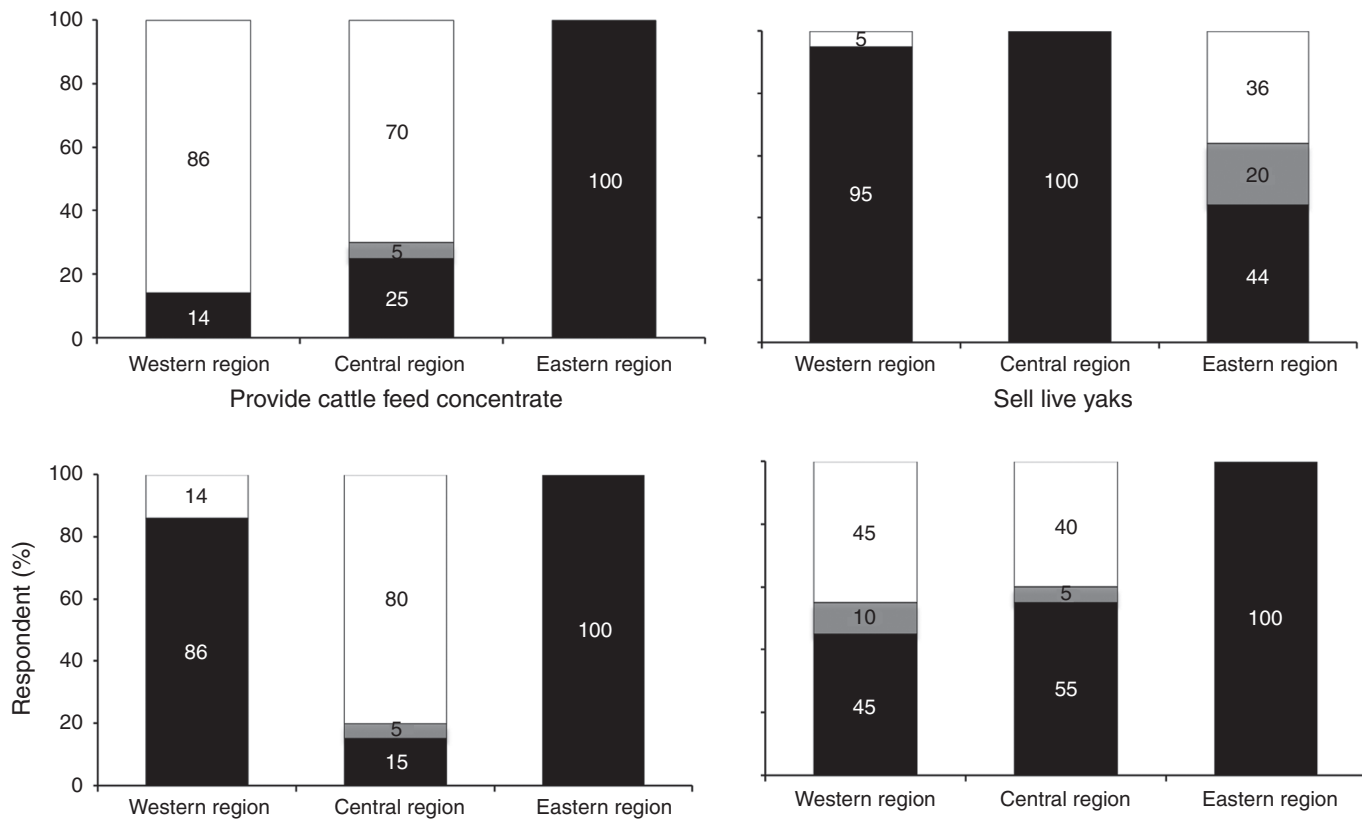

Provide radish and other crops
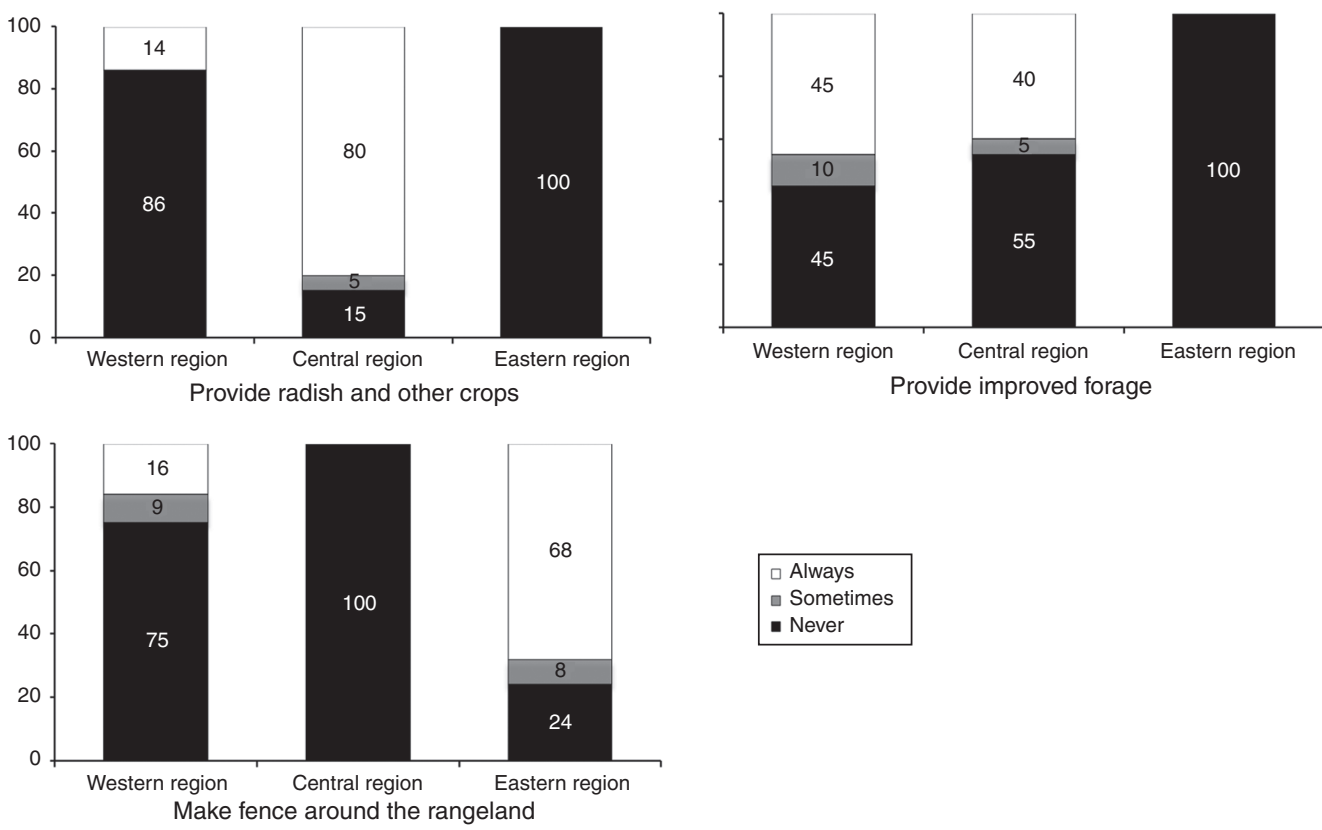

- Never

Fig. 2. Measures against forage shortage by yak herders in different regions (\%).

There was no association between characteristics of herders and the experienced yak mortality, except for herd size $(\beta=0.15, P=0.03$, odd ratio $=1.16,95 \% \mathrm{CI}=$ 1.05-1.39). For a unit increase in yak herd size, the probability of the yak herder to mention yak mortality as a problem increased by 1.16 times.

Table 6 presents the causes of yak mortality indicated by herders and livestock professionals. Herders (96\%) and livestock professionals (96\%) believed that wildlife predators attributed substantially to yak mortality $(P>$ $0.05)$. In addition, both herders $(67 \%)$ and livestock professionals (88\%) mentioned accidents to be a cause of death among yaks. A high number of yak accidents seemed to occur during forage shortage when animals were walking towards high-risk areas to obtain forage. Only few herders believed that poisonous plants, contaminated drinking water, unavailability of veterinary care, absence of sheds for yaks, and cold and bad weather conditions were causes of yak mortality. In contrast, more than half of the livestock professionals thought that these factors did contribute to yak mortality. Regional differences on the yak mortality were found for gid (Coenurus multiceps multiceps) infestation (western region) and outbreak of diseases (eastern region).

Herders had limited strategies to cure sick yaks and to prevent them from getting sick (Fig. 3). Most of the herders visited or contacted livestock extensionist to treat sick yaks in occasional or in the majority of cases. Furthermore, many herders sought advice from neighbouring yak herders to treat sick yaks. Herders in the western $(91 \%)$ and central $(70 \%)$ regions spent extra time to look after the sick yaks, whereas, in the eastern region, this was often not undertaken. In the western region, local practitioners (healers) also treated yaks that had, for example, fractured limbs and bones. In the western and central regions, local rituals for divine support were conducted, which, in most situations, was a scent offering. Vaccinations and annual local rituals were performed to prevent yaks from getting sick by at least $64 \%$ of the herders in all regions.

\section{Perceived level of changes in yak farming}

Table 7 shows the herders' and livestock professionals' perceived level of changes on aspects related to yak 
Table 6. Yak herders' $(n=62)$ experience and livestock professionals' $(n=25)$ view on aspects affecting yak mortality (see for details per region Appendix 2)

$P$-values are given (Mann-Whitney $U$ test)

\begin{tabular}{|c|c|c|c|c|c|c|}
\hline \multirow[t]{2}{*}{ Respondent group } & \multicolumn{5}{|c|}{ Level of effect on yak mortality (\%) } & \multirow[t]{2}{*}{$P$ - value } \\
\hline & Not at all & Small extent & Moderate extent & Large extent & Don't know & \\
\hline \multicolumn{7}{|c|}{ Lack of forage in rangelands } \\
\hline Yak herders & 50 & 18 & 17 & 14 & 1 & 0.023 \\
\hline Livestock professionals & 28 & 16 & 24 & 32 & 0 & \\
\hline \multicolumn{7}{|c|}{ Water shortage } \\
\hline Yak herders & 79 & 11 & 6 & 3 & 1 & 0.093 \\
\hline Livestock professionals & 56 & 4 & 20 & 12 & 8 & \\
\hline \multicolumn{7}{|c|}{ Outbreak of diseases } \\
\hline Yak herders & 53 & 20 & 11 & 12 & 4 & 0.238 \\
\hline Livestock professionals & 32 & 24 & 16 & 12 & 16 & \\
\hline \multicolumn{7}{|c|}{ Gid infestation } \\
\hline Yak herders & 45 & 20 & 11 & 17 & 7 & 0.004 \\
\hline Livestock professionals & 20 & 12 & 24 & 44 & 0 & \\
\hline \multicolumn{7}{|c|}{ Plant poisoning } \\
\hline Yak herders & 58 & 36 & 3 & 3 & 0 & 0.000 \\
\hline Livestock professionals & 12 & 28 & 32 & 16 & 12 & \\
\hline \multicolumn{7}{|c|}{ Drinking contaminated water } \\
\hline Yak herders & 73 & 18 & 6 & 3 & 0 & 0.000 \\
\hline Livestock professionals & 24 & 24 & 28 & 25 & 0 & \\
\hline \multicolumn{7}{|c|}{ Unavailability of veterinary care } \\
\hline Yak herders & 70 & 15 & 9 & 5 & 1 & 0.005 \\
\hline Livestock professionals & 32 & 36 & 16 & 12 & 4 & \\
\hline \multicolumn{7}{|c|}{ Wildlife predators } \\
\hline Yak herders & 4 & 26 & 35 & 35 & 0 & 0.200 \\
\hline Livestock professionals & 4 & 20 & 20 & 56 & 0 & \\
\hline \multicolumn{7}{|c|}{ Poor shed quality or absence of shed } \\
\hline Yak herders & 74 & 15 & 8 & 2 & 1 & 0.001 \\
\hline Livestock professionals & 36 & 32 & 16 & 8 & 8 & \\
\hline \multicolumn{7}{|c|}{ Cold and bad weather conditions } \\
\hline Yak herders & 65 & 23 & 8 & 4 & 0 & 0.001 \\
\hline Livestock professionals & 28 & 24 & 28 & 16 & 4 & \\
\hline \multicolumn{7}{|c|}{ Accidents with yaks } \\
\hline Yak herders & 32 & 46 & 15 & 6 & 1 & 0.508 \\
\hline Livestock professionals & 12 & 76 & 4 & 8 & 0 & \\
\hline \multicolumn{7}{|c|}{ Heat stress } \\
\hline Yak herders & 100 & 0 & 0 & 0 & 0 & 0.000 \\
\hline Livestock professionals & 52 & 20 & 20 & 0 & 8 & \\
\hline
\end{tabular}

farming. Both herders (59\%) and livestock professionals $(36 \%)$ believed that the market for selling yak products has improved over the years. Still, $\sim 33 \%$ of the herders of the western region thought that the market for selling yak products had somewhat deteriorated. About half of the herders mentioned that the number of family members available to herd yaks had remained the same, while $66 \%$ of the livestock professionals thought this had decreased over the years. However, both herders (74\%) and livestock professionals (71\%) believed that the number of young people (potential successors) in the community had decreased compared with the past. For the number of yak farming households and the yak population in the communities, large regional differences were found. In the western region, $76 \%$ of the herders stated that the yak population in the community had decreased over the years. However, in the eastern region, $60 \%$ of the herders thought that both the yak population and the number of yak farming households had increased over the years. The yak herds were divided among family members when they settled with the new family, and this probably explained why the yak farming households and yak population in the eastern region had increased over the years.

Most herders and livestock professionals expressed that the forage availability had decreased in summer and winter compared with the past years. About half of the respondents (herders, 53\%; livestock professionals, $49 \%$ ) believed that 


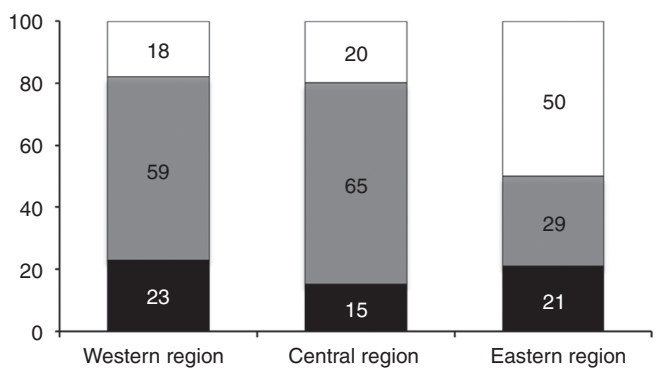

Call or visit livestock extension office
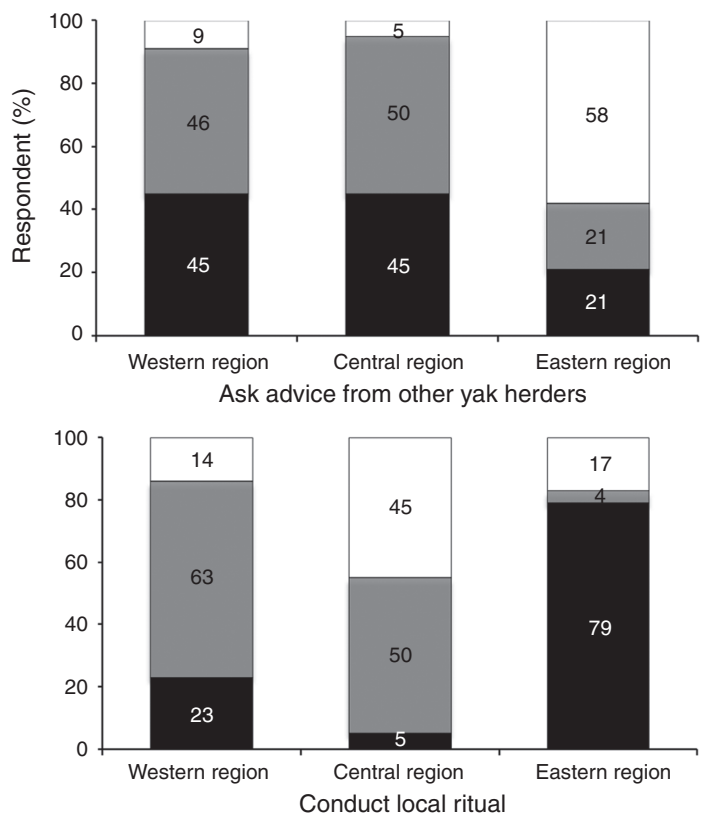

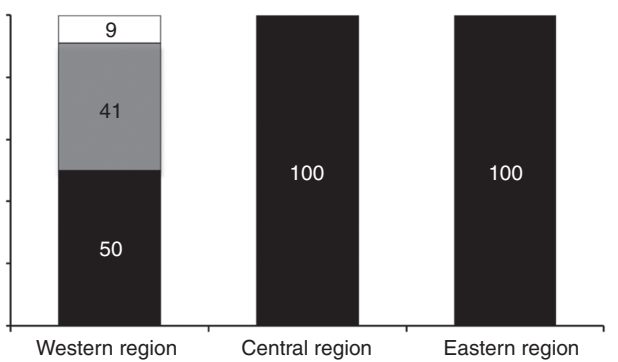

Seek assistance from the local header

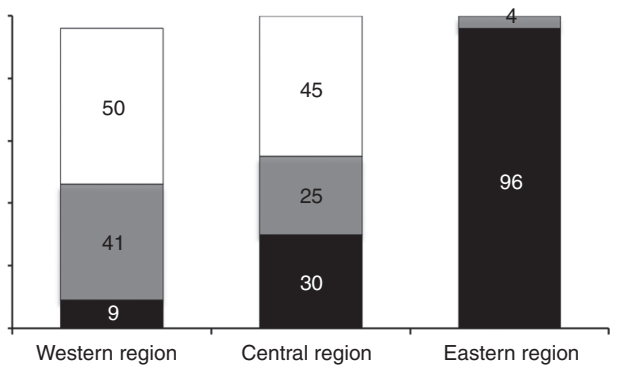

Increase time to look after sick yaks

Fig. 3. Yak herders' response to yaks having a health issue in three yak farming regions (\%).

wild carnivore predation on yaks had increased over the years. Equal proportions of the herders believed that the level of disease and parasites had remained the same (26\%), increased $(30 \%)$ or decreased $(30 \%)$ over the years. About $50 \%$ of livestock professionals thought that the level of diseases and parasites had decreased over the years. A majority of herders and livestock professionals indicated a better access to extension and health services in recent times.

\section{Discussion}

Herding yaks in Bhutan is often a family business, and herder perceptions on the change in yak farming practices are often based on experiences acquired over multiple years or even over generations (Stuiver et al. 2004). Although perceptions are subjective by nature, and only 3 of 25 yak farming blocks were visited, we believe the collected information from three regions is relevant for the future of yak farming. Moreover, data were collected from different livestock professionals who worked with yak-based communities, to supplement the information. The approach provided new insights and a better understanding of the current situation and developments in yak farming from different perspectives, both from those of the yak herders and livestock professionals.
The herders of different regions emphasised that they wanted to produce yak products for sale on the basis of customer preferences. Currently, herders and middlemen bring the yak products to local shops or urban areas to sell the products. Some herders sell their yak products along the motorway or barter yak products for cereals and grains with farmers in the lowland valley. In the past, most herders took yak products to the lowland valley and products were sold door-to-door. In this process, the host family of the herders played a crucial role in selling yak products. The host families provided a place for herders to stay when they reached the lowlands, and they also assisted in selling the yak products. Now, most herders said that they did not need assistance from their host family because selling yak products had improved over the years with the connection to motorways between these yak farming villages. However, most yak farming regions in Bhutan are not connected with roads, and road constructions are incomplete, or roads are poorly maintained. This probably explains why most livestock professionals formed the view that poor road transport and the distance between producers and urban areas were the main factors that affect selling of yak products. A proper marketing channel should be in place whereby herders can bring their yak products to the nearest 
Table 7. Yak herders' $(n=67)$ and livestock professionals' $(n=28)$ perceived level of change compared with the past years (for details per region, see Appendix 3)

$P$-values are given (Mann-Whitney $U$ test)

\begin{tabular}{|c|c|c|c|c|c|c|c|}
\hline \multirow[t]{2}{*}{ Respondent group } & \multicolumn{6}{|c|}{ Level of perceived changes (\%) } & \multirow[t]{2}{*}{$P$-value } \\
\hline & $\begin{array}{l}\text { Much } \\
\text { decreased }\end{array}$ & $\begin{array}{l}\text { Somewhat } \\
\text { decreased }\end{array}$ & $\begin{array}{l}\text { About } \\
\text { same }\end{array}$ & $\begin{array}{c}\text { Somewhat } \\
\text { increased }\end{array}$ & $\begin{array}{c}\text { Much } \\
\text { increased }\end{array}$ & $\begin{array}{l}\text { Don't } \\
\text { know }\end{array}$ & \\
\hline \multicolumn{8}{|c|}{ Market for selling yak products } \\
\hline Yak herders & 0 & 14 & 26 & 38 & 21 & 1 & 0.048 \\
\hline Livestock professionals & 11 & 14 & 29 & 25 & 11 & 11 & \\
\hline \multicolumn{8}{|c|}{ Labour availability to herd yaks } \\
\hline Yak herders & 14 & 24 & 53 & 9 & 0 & 0 & 0.007 \\
\hline Livestock professionals & 33 & 33 & 19 & 0 & 7 & 7 & \\
\hline \multicolumn{8}{|c|}{ Successor (youth) to yak farming } \\
\hline Yak herders & 23 & 51 & 17 & 6 & 0 & 3 & 0.078 \\
\hline Livestock professionals & 18 & 36 & 35 & 0 & 0 & 11 & \\
\hline \multicolumn{8}{|c|}{ Yak farming household number } \\
\hline Yak herders & 20 & 24 & 24 & 23 & 9 & 0 & 0.076 \\
\hline Livestock professionals & 21 & 47 & 7 & 14 & 4 & 7 & \\
\hline \multicolumn{8}{|c|}{ Size of yak population in the community } \\
\hline Yak herders & 4 & 32 & 26 & 27 & 11 & 0 & 0.152 \\
\hline Livestock professionals & 14 & 18 & 36 & 25 & 0 & 7 & \\
\hline \multicolumn{8}{|c|}{ Forage availability in winter rangeland } \\
\hline Yak herders & 35 & 41 & 23 & 1 & 0 & 0 & 0.030 \\
\hline Livestock professionals & 11 & 57 & 18 & 11 & 3 & 0 & \\
\hline \multicolumn{8}{|c|}{ Forage availability in summer rangeland } \\
\hline Yak herders & 21 & 62 & 17 & 0 & 0 & 0 & 0.005 \\
\hline Livestock professionals & 4 & 57 & 29 & 7 & 3 & 0 & \\
\hline \multicolumn{8}{|c|}{ Wild-carnivore predation on yaks } \\
\hline Yak herders & 0 & 14 & 26 & 20 & 33 & 7 & 0.474 \\
\hline Livestock professionals & 11 & 11 & 22 & 19 & 30 & 7 & \\
\hline \multicolumn{8}{|c|}{ Prevalence of diseases and parasites } \\
\hline Yak herders & 6 & 24 & 26 & 27 & 3 & 14 & 0.049 \\
\hline Livestock professionals & 14 & 36 & 36 & 11 & 4 & 0 & \\
\hline \multicolumn{8}{|c|}{ Access to veterinary and health services } \\
\hline Yak herders & 2 & 3 & 21 & 64 & 11 & 0 & 0.239 \\
\hline Livestock professionals & 11 & 11 & 25 & 32 & 21 & 0 & \\
\hline
\end{tabular}

market areas or form a yak herder association to collect yak products and market them. Moreover, establishing a nichemarketing strategy for yak products by branding and standard package design (adding value) could be of great value to stimulate the sales of yak products in Bhutan.

Herders of the western and central yak farming region mentioned that the males were involved with tourism, cordyceps collection, and other high-revenue economic activities. Consequently, females performed the entire task of yak herding. On the one hand, the increased involvement of women in yak herding may be viewed as a promotion of gender equality because women have equal access to and control over the resources (Wangchuk and Wangdi 2015). On the other hand, it may be argued that women have increased responsibilities beside the daily household chores they are expected to conduct, as males are involved in off-farm work. Because of the increased involvement of women in yak herding, managing a yak herd will become more difficult.
Consequently, the yak farming family will experience labour shortages.

Modernisation (e.g. education, better roads) has certainly improved the living standards of yak-based families in Bhutan, but it has had repercussions on the availability of family labour to herd yaks. In the past, children assisted their parents in yak herding. Nowadays, most yak-based families send their children to school to improve their living standard. Most respondents said that the literate youth often seemed to view yak farming as an old-fashioned way of supporting their livelihood. Respondents also said that the literate young family members often left their village for towns because there were modern technologies available, better job opportunities, education and health care. Literate young family members who remained in the village were also not interested in yak farming because this practice had lower economic returns than did other livelihoods. Access to modern education for the children of yak-based families, 
therefore, seemed to be a major underlying cause of labour shortage to herd yaks.

The decreased number of young family members (successors) to take over yak farming compared with the past was expressed in many discussions with yak herders. The number of yak farming households may, therefore, decrease. For example, six advanced-age herders felt that yak herding had become more difficult for them because of the large distances to walk with the yaks. These six herders would certainly leave yak farming soon, but they had no successor. In interviews with non-yak farmers of the same village (data not shown in Results section), seven of eight respondents stated that they left yak farming $\sim 4$ years ago because of the labour shortage. This was also found in the district of Haa (western Bhutan), where 90 households have left yak farming in the past 20 years due to labour shortage (Norbu 2012). It illustrates that the labour availability to herd yaks is a key factor for the future of yak farming in Bhutan.

Following the example of collaborative reindeer herding in Norway (Thomas et al. 2018), a stronger social cohesion involving active collaboration could partly reduce labour shortages in yak herding. Another strategy is to explore novel sustainable sources of income based on yak farming, to ensure the viability of yak farming. For example, most herders mentioned that the use of horses is the only benefit they have from tourism. Community-based tourism could be promoted, where local people obtain a bigger role in tourism, such as, for example, in planning and administration (Suntikul and Dorji 2016). Community-based tourism is likely to encourage young and adult family members to remain in yak farming.

Similar to yak-based transhumant families in Nepal (Aryal et al. 2014), and to cattle-based transhumant families in Switzerland (Jurt et al. 2015) and Bhutan (Namgay et al. 2014), engagement in high-revenue economic activities is perceived as a cause of labour shortages in yak-based transhumant families in Bhutan. In Bhutan, cordyceps collection, legalised in 2004, is such an activity. Cordyceps collection improved enormously the lives of yak-based families of the western and central region. Herders said that they were able to send their children to school, purchase yaks, horses, or a house or land in the lowland valleys. The cordyceps collection generated high revenues in the short term, but the current way of collection might not be sustainable in the long term. In the interview, many herders mentioned that the cordyceps harvest had decreased over the years due to increased number of cordyceps collectors, which is in agreement with the results of other studies (Negi et al. 2006; Shrestha and Bawa 2014). So, if the situation does not change, the communities may need to rely less on cordyceps in the future. Moreover, herders mentioned that the cordyceps collection in the summer rangelands caused increased forage shortage due to the many horses that transport food items and other basic necessities for the collectors that graze on these rangelands. The summer rangeland carrying capacity is $\sim 0.05$ livestock units per hectare (Wangchuk et al. 2013b). In Bhutan, one livestock unit is defined as an adult yak weighing $300 \mathrm{~kg}$ with a daily dry-matter requirement of $2 \%$ of live bodyweight (Samdup et al. 2010). Therefore, the extra horses grazing on these rangelands contributed to over-grazing (Wangchuk and Wangdi 2015). In the western region, tourism also increased the presence of horses, placing greater pressure on forage availability. Herders stated that they needed $\sim 50$ horses for 15 tourists during trekking and camping to Lunana (T. Phuntsho, pers. comm.). The increased equine population over the years as indicated by yak herders corresponded with the increased equine population by $100 \%$ in the western region between 2008 and 2018 (DoL 2008, 2018).

Although herders did not mention the increased presence of stray dogs in the community, livestock extensionist of the neighbour block stated that because of tourists, food wastes were produced, which attracted stray dogs to yak farming regions. These stray dogs freely roam nearby yak farming villages, and during food scarcity they sometimes attacked young yaks, which has been estimated to cause the death of 15-20 young yaks annually over the past 5 years in Lunana block (J. Rizin, pers. comm.). These stray dogs not only cause yak mortality, they are also the host of gid. Gid is a parasitic disease that infects young yaks below 3 years of age. Young yaks are infected when they graze on pasture contaminated with dog faeces infested with eggs of the tapeworm. The eggs of the tapeworm hatch to become larvae in the small intestine of yaks, and then the larvae travel from the intestine to the brain, where they develop into cysts. In the western yak farming region, gid infestation in young yaks has been the major important cause of calf mortality, and herders believed that this gid infestation has increased over the years, even though they dewormed their yak calves.

In the regions under study, yak predation by wild, often endangered, predators (e.g. tiger, snow leopard, bear, Asiatic wild dog) was said to be the main source of tension between herders and wildlife. Yaks freely graze on the rangelands during the day, where they mostly remain unattended by the herders (they return to the campsite), and, therefore, become more vulnerable to predator attacks. Although herders did not mention it, Bhutan's strong conservation policy to protect wild endangered predators could contribute to yak mortality, because most respondents mentioned that the yak predation by wild predators had increased over the years. However, a decline in wild prey or livestock outnumbering wild prey populations (Suryawanshi et al. 2017), and predators' habitat loss could contribute to increased yak predation. Because yaks were the mainstay economy of yak-based families in Bhutan, the increased number of wild-predator attacks on yak is an important issue that requires appropriate mitigation measures to minimise this human-wildlife conflict. An alternative solution to human-wildlife conflicts may focus on compensating farmers for the loss of livestock through predation (Ikeda 2004; Namgail et al. 2007). Other measures that could be effective are training and education of yak herders on wild predators, corralling young and weak yaks, and improving yak management practices (Treves and Karanth 2003). Preventing forage shortage could also reduce the number of yak predations because yaks stray away from the main herd when they experience forage shortage, making them more prone to predator attacks.

Herders of the central and eastern regions mentioned that the ban on burning of rangelands and prohibition of clearing 
bushes in the rangelands (e.g. Forest and Nature Conservation Act 1995) have increased forage shortage due to receding rangelands. Fire is an effective tool to control spread of these shrubs in the rangeland (Sharma et al. 2014). Recently, (Wangchuk et al. 2013b) showed that prescribed burning could increase the carrying capacity of rangeland from 0.05 to 0.23 livestock unit per ha in Bhutan; they further recommended to perform one prescribed burning every 6 years to maintain the quality of rangeland. To have control and safe burning of areas a local herder association could be established, such as, for example, similarly to the Prescribed Burn Associations established in United States. Such associations should train herders and stimulate them to assist each other in executing prescribed fires on the rangelands (Weir et al. 2016). In contrast, it may be argued that the shrub proliferation increases biodiversity and carbon sequestration capacity and improves soil fertility (Maestre et al. 2016).

The response of herders to cope with labour shortage, forage shortage and yak mortality is mostly based on herders' traditional knowledge and skills. For example, during forage shortage, herders of western and central regions provide supplementary feed and forages that they generally purchased from lowland farmers. In the eastern region, most herders have taken preventive measures to combat forage shortage by constructing and maintaining fences around the rangeland, to keep away other animals. However, the Land Act 2007 does not allow herders to build or renovate fences, and yaks and other animals owned by other family members trespass the rangeland, which results in conflicts among rangeland users (Wangdi and Norbu 2018). So far, the Land Act 2007 of Bhutan has not been implemented, yet herders mentioned that the rangeland conflicts have increased because rangeland users (other yak herders, horse and cattle-yak hybrid owners) do not follow agreed norms and rules of communities on the use of rangelands. In agreement with the current study, conflicts as consequences of leasing rangeland also were observed in Nepal after the nationalisation of rangeland in 1957 (Dong et al. 2016).

Our results showed that most livestock professionals were aware of herders' experience and perception on labour shortage, forage shortage and yak mortality. However, some underlying causes to forage shortage, labour shortage and yak mortality as perceived by the livestock professionals were different from those perceived by the herders. Most livestock professionals strongly viewed that the young and adult family members of yak-based communities were increasingly engaged with high-revenue economic activities. This possibly explains why most of the livestock professionals think that the yak-based communities face a labour shortage. However, herders in the western region mentioned that only their horses are hired by tourist operators and middle persons, while the herders are not involved in tourism. Herders in the western and central regions collected cordyceps only for 2 months in a year, facing a potential labour shortage only in that period. Similarly, more than half of the livestock professionals thought that increased herd sizes caused forage shortages, which contradicts the herders' view. But herders tended to blame each other for the forage shortage.
Despite herders' professionalism on yak farming, they may be unaware of the impact of harsh weather conditions and absence of protective sheds to assist in the maintenance of the health and welfare of yaks. The livestock professionals have a high level of education and might be better informed by using data records, which could be a reason for a different opinion, whereas herders mostly do not keep records, and their view is based on their experience.

Livestock professionals should encourage the herders to be more vigilant and to supervise their yaks regularly to prevent predation and yaks from drinking contaminated water and eating poisonous plants. For example, when yak feed on senecio and crotalaria plants, which are the first plants to appear in the early spring, they consume pyrrolizidine alkaloids, which might cause skin lesions and liver damage (Winter et al. 1992).

\section{Conclusions}

Yak-based transhumant pastoralism in Bhutan is affected by socioeconomic developments and regulation. Forage shortage and yak mortality were the main challenges experienced by herders. The market to sell yak products, livestock extension and health services for yaks have improved over the years due to better connection to passable roads. However, forage shortage and yak predation have increased over the years because of strong environmental policies and competition for available rangelands. Labour availability has reduced slightly, and the number of family successors staying in the industry has decreased over the years due to education and other sources of income. Without change of policy, the number of yak-based farming households will decline further in the future.

\section{Conflicts of interest}

The authors declare no conflicts of interest.

\section{Acknowledgements}

The funding agency Netherlands University Foundation for International Cooperation is highly acknowledged. The authors thank the livestock extensionists and the local health worker of the study sites for their sincere support during the field visits. The authors further thank all respondents for participating in the study.

\section{References}

Allen VG, Batello C, Berretta EJ, Hodgson J, Kothmann M, Li X, McIvor J, Milne J, Morris C, Peeters A, Sanderson M (2011) An international terminology for grazing lands and grazing animals. Grass and Forage Science 66, 2-28. doi:10.1111/j.1365-2494.2010.00780.x

Aryal S, Maraseni TN, Cockfield G (2014) Sustainability of transhumance grazing systems under socio-economic threats in Langtang, Nepal. Journal of Mountain Science 11, 1023-1034. doi:10.1007/s11629013-2684-7

Corti L, Day A, Backhouse G (2000) Confidentiality and informed consent: issues for consideration in the preservation of and provision of access to qualitative data archives. Forum: Qualitative Social Research 1. doi:10.17169/fqs-1.3.1024

Derville M, Bonnemaire J (2010) 'Marginalisation of yak herders in Bhutan: can public policy generate new stabilities that can support the transformation of their skills and organisations and bonds to 
territories: a case study in France and Brazil.' (ISDA: Montpellier, France)

DoL (2008) 'Livestock statistics 2008.' (Ministry of Agriculture and Forests: Thimphu: Bhutan) pp. 163.

DoL (2018) 'Livestock statistics 2018.' (Ministry of Agriculture and Forests: Thimphu: Bhutan) pp. 342.

Dong S, Yi SL, Yan ZL (2016) Maintaining the human-natural systems of pastoralism in the Himalayas of south Asia and China. In 'Building resilience of human-natural systems of pastoralism in the developing world: interdisciplinary perspectives'. (Eds S Dong, K-AS Kassam, JF Tourrand, RB Boone) pp. 93-135. (Springer International Publishing: Cham, Switzerland)

Gyamtsho P (2000) Economy of yak herders. Journal of Bhutan Studies 2, $1-45$.

Heckathorn DD, Cameron CJ (2017) Network sampling: from snowball and multiplicity to respondent-driven sampling. Annual Review of Sociology 43, 101-119. doi:10.1146/annurev-soc-060116-053556

Ikeda N (2004) Economic impacts of livestock depredation by snow leopard Uncia uncia in the Kanchenjunga Conservation Area, Nepal Himalaya. Environmental Conservation 31, 322-330. doi:10.1017/S0376892 904001778

Jurt C, Häberli I, Rossier R (2015) Transhumance farming in Swiss mountains: adaptation to a changing environment. Mountain Research and Development 35, 57-65. doi:10.1659/MRD-JOURNAL-D-1400022.1

Maestre FT, Eldridge DJ, Soliveres S (2016) A multifaceted view on the impacts of shrub encroachment. Applied Vegetation Science 19, 369-370. doi:10.1111/avsc. 12254

McVeigh C (2004) Himalayan herding is alive and well: the economics of pastoralism in the Langtang valley. Nomadic Peoples 8, 107-124. doi: $10.3167 / 082279404780446023$

Namgail T, Fox JL, Bhatnagar YV (2007) Carnivore-caused livestock mortality in Trans-Himalaya. Environmental Management 39, 490-496. doi:10.1007/s00267-005-0178-2

Namgay K, Millar JE, Black RS, Samdup T (2014) Changes in transhumant agro-pastoralism in Bhutan: a disappearing livelihood? Human Ecology 42, 779-792. doi:10.1007/s10745-014-9684-2

Negi CS, Koranga PR, Ghinga HS (2006) Yar tsa gumba (Cordyceps sinensis): a call for its sustainable exploitation. International Journal of Sustainable Development and World Ecology 13, 165-172. doi:10.1080/13504500609469669

Norbu P (2012) 'Haa: Yak herding: a vanishing way of life.' (Kuensel: Thimphu, Bhutan)

Phuntsho K, Dorji T (2016) Yak herding in Bhutan: policy and practice. In 'Transboundary challenges and opportunities for yak raising in a changing Hindu Kush Himalayan region'. (Eds N Wu, S Yi, S Joshi, N Bisht) pp. 147-163. (International Centre for Integrated Mountain Development: Kathmandu, Nepal)

R Core Team (2017) R: A language and environment for statistical computing. R Foundation for Statistical Computing, Vienna, Austria. Available at https://www.R-project.org/ [Verified 16 June 2020]

Samdup T, Udo HMJ, Eilers CHAM, Ibrahim MNM, van der Zijpp AJ (2010) Crossbreeding and intensification of smallholder crop-cattle farming systems in Bhutan. Livestock Science 132, 126-134. doi:10.1016/j.livsci.2010.05.014

Sharma LN, Vetaas OR, Chaudhary RP, Måren IE (2014) Pastoral abandonment, shrub proliferation and landscape changes: a case study from Gorkha, Nepal. Landscape Research 39, 53-69. doi:10.1080/ 01426397.2013.773299

Shrestha UB, Bawa KS (2014) Economic contribution of Chinese caterpillar fungus to the livelihoods of mountain communities in Nepal. Biological Conservation 177, 194-202. doi:10.1016/j. biocon.2014.06.019

Stuiver M, Leeuwis C, van der Ploeg JD (2004) 'The power of experience: farmers' knowledge and sustainable innovations in agriculture. In 'Seeds of transition: essays on novelty production, niches and regimes in agriculture'. (Eds JSC Wiskerke, JD van der Ploeg) pp. 93-118 (Royal Van Gorcum: Assen, Netherlands) Available at https://edepot.wur.nl/338074 [Verified 25 July 2019]

Suntikul W, Dorji UCJTRR (2016) Tourism development: the challenges of achieving sustainable livelihoods in Bhutan's remote reaches. International Journal of Tourism Research 18, 447-457. doi:10.1002/ jtr.2062

Suryawanshi KR, Redpath SM, Bhatnagar YV, Ramakrishnan U, Chaturvedi V, Smout SC, Mishra C (2017) Impact of wild prey availability on livestock predation by snow leopards. Royal Society Open Science 4, 170026. doi:10.1098/rsos. 170026

Thomas MG, Bårdsen B-J, Næss MW (2018) The narrow gap between norms and cooperative behaviour in a reindeer herding community Royal Society Open Science 5, 171221. doi:10.1098/rsos.171221

Treves A, Karanth UK (2003) Human-carnivore conflict and perspectives on carnivore management worldwide. Conservation Biology 17, 1491-1499. doi:10.1111/j.1523-1739.2003.00059.x

Wangchuk K, Wangdi J (2015) Mountain pastoralism in transition: consequences of legalizing Cordyceps collection on yak farming practices in Bhutan. Pastoralism 5, 4. doi:10.1186/s13570-015-0025-x

Wangchuk D, Dhammasaccakarn W, Tepsing P, Sakolnakarn TPN (2013a) The yaks: heart and soul of the Himalayan tribes of Bhutan E3 Journal of Environmental Research and Management 4, 0189-0196.

Wangchuk K, Gyaltshen T, Yonten T, Nirola H, Tshering N (2013b) Shrubland or pasture? Restoration of degraded meadows in the mountains of Bhutan. Mountain Research and Development 33, 161-169. doi:10.1659/MRD-JOURNAL-D-12-00091.1

Wangdi J (2016) The future of yak farming in Bhutan: policy measures government should adopt. The Rangeland Journal 38, 367-371. doi:10.1071/RJ15111

Wangdi S, Norbu N (2018) Good fences are key to sustainable pasture management and harmonious pastoral society of Merak and Sakteng in Bhutan. Pastoralism 8, 4. doi:10.1186/s13570-017-0106-0

Weir JR, Twidwell D, Wonkka CL (2016) From grassroots to national alliance: the emerging trajectory for landowner prescribed burn associations. Rangelands 38,113-119. doi:10.1016/j.rala.2016.02.005

Winter H, Seawright AA, Hrdlicka J, Tshewang U, Gurung JB (1992) Pyrrolizidine alkaloid poisoning of yaks (Bos grunniens) confirmation by recovery of pyrrolic metabolites from formalin-fixed liver tissue. Research in Veterinary Science 52, 187-194. doi:10.1016/0034-5288 (92)90009-Q

Handling editor: Peter Wynn 
Appendix 1. Yak herders' (western, $n=20$; central, $n=20$; eastern, $n=22$ ) view on aspects with the level of effect on forage availability in different yak farming regions (\%)

\begin{tabular}{|c|c|c|c|c|c|c|}
\hline \multirow[t]{2}{*}{ Region } & \multicolumn{5}{|c|}{ Level of effect on forage availability } & \multirow[t]{2}{*}{$P$-value } \\
\hline & Not at all & Small extent & Moderate extent & Large extent & Don't know & \\
\hline \multicolumn{7}{|c|}{ Increased in family yak herd size } \\
\hline Western region & 59 & 14 & 23 & 4 & 0 & 0.382 \\
\hline Central region & 75 & 10 & 5 & 10 & 0 & \\
\hline Eastern region & 72 & 12 & 12 & 0 & 4 & \\
\hline \multicolumn{7}{|c|}{ Increase community yak herd size } \\
\hline Western region & 59 & 9 & 23 & 9 & 0 & 0.315 \\
\hline Central region & 50 & 15 & 25 & 10 & 0 & \\
\hline Eastern region & 20 & 8 & 36 & 32 & 4 & \\
\hline \multicolumn{7}{|c|}{ Increase competition with cattle-yak hybrids } \\
\hline Western region $^{\mathrm{A}}$ & 77 & 0 & 14 & 5 & 5 & 0.002 \\
\hline Central region & 25 & 10 & 40 & 20 & 5 & \\
\hline Eastern region & 24 & 12 & 20 & 40 & 4 & \\
\hline \multicolumn{7}{|c|}{ Increase competition with horse } \\
\hline Western region & 9 & 18 & 27 & 46 & 0 & 0.005 \\
\hline Central region & 70 & 5 & 10 & 15 & 0 & \\
\hline Eastern region & 48 & 40 & 0 & 12 & 0 & \\
\hline \multicolumn{7}{|c|}{ Rangeland division among family members } \\
\hline Western region & 68 & 9 & 5 & 14 & 0 & 0.000 \\
\hline Central region & 95 & 5 & 0 & 0 & 0 & \\
\hline Eastern region & 24 & 4 & 4 & 68 & 0 & \\
\hline \multicolumn{7}{|c|}{ Cordyceps collection site } \\
\hline Western region & 45 & 18 & 18 & 19 & 0 & 0.000 \\
\hline Central region & 40 & 10 & 20 & 30 & 0 & \\
\hline Eastern region & 100 & 0 & 0 & 0 & 0 & \\
\hline \multicolumn{7}{|c|}{ Prohibited burn the rangeland } \\
\hline Western region & 68 & 5 & 18 & 10 & 0 & 0.017 \\
\hline Central region & 15 & 10 & 40 & 30 & 5 & \\
\hline Eastern region & 24 & 8 & 8 & 60 & 0 & \\
\hline \multicolumn{7}{|c|}{ Rangeland lease (Land Act 2007) } \\
\hline Western region & 68 & 0 & 9 & 18 & 5 & 0.077 \\
\hline Central region & 85 & 0 & 0 & 5 & 10 & \\
\hline Eastern region & 44 & 4 & 0 & 16 & 36 & \\
\hline \multicolumn{7}{|c|}{ Less rainfall amount } \\
\hline Western region & 36 & 32 & 27 & 5 & 0 & 0.049 \\
\hline Central region & 65 & 20 & 5 & 0 & 10 & \\
\hline Eastern region $^{\mathrm{B}}$ & 44 & 16 & 16 & 0 & 16 & \\
\hline \multicolumn{7}{|c|}{ Soil erosion } \\
\hline Western region & 55 & 9 & 28 & 8 & 0 & 0.491 \\
\hline Central region & 75 & 20 & 5 & 0 & 0 & \\
\hline Eastern region & 52 & 20 & 14 & 13 & 0 & \\
\hline \multicolumn{7}{|c|}{ Less snow cover on rangeland } \\
\hline Western region ${ }^{\mathrm{C}}$ & 32 & 14 & 18 & 0 & 4 & 0.004 \\
\hline Central region & 75 & 5 & 5 & 0 & 15 & \\
\hline Eastern region $^{\mathrm{C}}$ & 48 & 8 & 8 & 12 & 20 & \\
\hline \multicolumn{7}{|c|}{ Declare rangeland as protected areas } \\
\hline Western region & 73 & 9 & 18 & 0 & 0 & 0.001 \\
\hline Central region & 100 & 0 & 0 & 0 & 0 & \\
\hline Eastern region & 100 & 0 & 0 & 0 & 0 & \\
\hline \multicolumn{7}{|c|}{ Protect community forest } \\
\hline Western region & 68 & 18 & 5 & 0 & 9 & 0.237 \\
\hline Central region & 100 & 0 & 0 & 0 & 0 & \\
\hline Eastern region & 100 & 0 & 0 & 0 & 0 & \\
\hline \multicolumn{7}{|c|}{ Increase competition with wild herbivore } \\
\hline Western region & 55 & 18 & 18 & 5 & 5 & 0.000 \\
\hline Central region & 35 & 25 & 35 & 5 & 0 & \\
\hline Eastern region & 100 & 0 & 0 & 0 & 0 & \\
\hline
\end{tabular}

${ }^{\mathrm{A}}$ In the western region, cattle was reared but not cattle-yak hybrids.

${ }^{\mathrm{B}}$ Heavy rainfall in summer cause forage shortage.

${ }^{\mathrm{C}}$ The rest viewed that more snow coverage on the rangeland cause forage shortage. 
Appendix 2. Yak herders' (western, $n=22$; eastern, $n=21$; central, $n=19$ ) experience on aspects with level of effect on yak mortality in different regions (\%)

\begin{tabular}{|c|c|c|c|c|c|c|}
\hline \multirow[t]{2}{*}{ Region } & \multicolumn{5}{|c|}{ Level of effect on yak mortality } & \multirow[t]{2}{*}{$\overline{P \text {-value }}$} \\
\hline & Not at all & Small extent & Moderate extent & Large extent & Don't know & \\
\hline \multicolumn{7}{|c|}{ Lack of forage in rangelands } \\
\hline Western region & 41 & 23 & 18 & 18 & 0 & 0.189 \\
\hline Central region & 75 & 20 & 5 & 0 & 0 & \\
\hline Eastern region & 38 & 13 & 25 & 21 & 4 & \\
\hline \multicolumn{7}{|c|}{ Water shortage } \\
\hline Western region & 82 & 5 & 9 & 4 & 0 & 0.972 \\
\hline Central region & 70 & 10 & 10 & 5 & 5 & \\
\hline Eastern region & 83 & 17 & 0 & 0 & 0 & \\
\hline \multicolumn{7}{|c|}{ Outbreak of diseases } \\
\hline Western region & 64 & 18 & 14 & 4 & 0 & 0.000 \\
\hline Central region & 75 & 10 & 0 & 0 & 15 & \\
\hline Eastern region & 25 & 29 & 17 & 29 & 0 & \\
\hline \multicolumn{7}{|c|}{ Gid infestation } \\
\hline Western region & 0 & 27 & 23 & 50 & 0 & 0.000 \\
\hline Central region & 70 & 25 & 5 & 0 & 0 & \\
\hline Eastern region & 67 & 8 & 4 & 0 & 21 & \\
\hline \multicolumn{7}{|c|}{ Plant poisoning } \\
\hline Western region & 41 & 55 & 0 & 4 & 0 & 0.003 \\
\hline Central region & 45 & 45 & 10 & 0 & 0 & \\
\hline Eastern region & 83 & 13 & 0 & 4 & 0 & \\
\hline \multicolumn{7}{|c|}{ Drinking contaminated water } \\
\hline Western region & 73 & 18 & 4 & 5 & 0 & 0.010 \\
\hline Central region & 50 & 30 & 15 & 5 & 0 & \\
\hline Eastern region & 92 & 8 & 0 & 0 & 0 & \\
\hline \multicolumn{7}{|c|}{ Unavailability of veterinary care } \\
\hline Western region & 50 & 32 & 14 & 4 & 0 & 0.011 \\
\hline Central region & 80 & 5 & 5 & 5 & 5 & \\
\hline Eastern region & 79 & 9 & 8 & 4 & 0 & \\
\hline \multicolumn{7}{|c|}{ Wild-carnivore predation on yaks } \\
\hline Western region & 0 & 23 & 27 & 50 & 0 & 0.583 \\
\hline Central region & 0 & 20 & 40 & 40 & 0 & \\
\hline Eastern region & 13 & 33 & 38 & 17 & 0 & \\
\hline \multicolumn{7}{|c|}{ Poor shed quality or absence of shed } \\
\hline Western region & 64 & 27 & 9 & 0 & 0 & 0.169 \\
\hline Central region & 80 & 5 & 10 & 5 & 0 & \\
\hline Eastern region & 79 & 13 & 4 & 0 & 4 & \\
\hline \multicolumn{7}{|c|}{ Cold and bad weather conditions } \\
\hline Western region & 59 & 27 & 9 & 5 & 0 & 0.035 \\
\hline Central region & 50 & 35 & 10 & 5 & 0 & \\
\hline Eastern region & 84 & 8 & 4 & 4 & 0 & \\
\hline \multicolumn{7}{|c|}{ Accidents with yaks } \\
\hline Western region & 27 & 45 & 14 & 14 & 0 & 0.758 \\
\hline Central region & 30 & 55 & 10 & 0 & 5 & \\
\hline Eastern region & 38 & 38 & 21 & 4 & 0 & \\
\hline
\end{tabular}


Appendix 3. Yak herders' (western, $n=22$; central, $n=20$; eastern, $n=25$ ) perceived level of change on aspects compared with past years in different regions (\%)

\begin{tabular}{|c|c|c|c|c|c|c|c|}
\hline \multirow[t]{2}{*}{$\overline{\text { Region }}$} & \multicolumn{6}{|c|}{ Level of perceived changes } & \multirow[t]{2}{*}{$\overline{P \text {-value }}$} \\
\hline & $\begin{array}{c}\text { Much } \\
\text { decreased }\end{array}$ & $\begin{array}{c}\text { Somewhat } \\
\text { decrease }\end{array}$ & $\begin{array}{l}\text { About } \\
\text { Same }\end{array}$ & $\begin{array}{l}\text { Somewhat } \\
\text { increased }\end{array}$ & $\begin{array}{c}\text { Much } \\
\text { increased }\end{array}$ & $\begin{array}{l}\text { Don't } \\
\text { know }\end{array}$ & \\
\hline \multicolumn{8}{|c|}{ Market for selling yak products } \\
\hline Western region & 0 & 33 & 38 & 19 & 10 & 0 & \multirow[t]{3}{*}{0.233} \\
\hline Central region & 0 & 10 & 15 & 35 & 35 & 5 & \\
\hline Eastern region & 0 & 0 & 24 & 56 & 20 & 0 & \\
\hline \multicolumn{8}{|c|}{ Labour availability to herd yaks } \\
\hline Western region & 14 & 29 & 52 & 5 & 0 & 0 & \multirow[t]{3}{*}{0.653} \\
\hline Central region & 15 & 15 & 60 & 10 & 0 & 0 & \\
\hline Eastern region & 12 & 28 & 48 & 12 & 0 & 0 & \\
\hline \multicolumn{8}{|c|}{ Having successor to yak farming } \\
\hline Western region & 14 & 62 & 24 & 0 & 0 & 0 & \multirow[t]{3}{*}{0.206} \\
\hline Central region & 45 & 40 & 10 & 0 & 0 & 5 & \\
\hline Eastern region & 12 & 52 & 16 & 16 & 0 & 4 & \\
\hline \multicolumn{8}{|c|}{ Size of yak population in your community } \\
\hline Western region & 5 & 71 & 10 & 14 & 0 & 0 & \multirow[t]{3}{*}{0.018} \\
\hline Central region & 5 & 10 & 50 & 20 & 15 & 0 & \\
\hline Eastern region & 4 & 16 & 20 & 44 & 16 & 0 & \\
\hline \multicolumn{8}{|c|}{ Yak farming household number } \\
\hline Western region & 33 & 48 & 14 & 5 & 0 & 0 & \multirow[t]{3}{*}{0.777} \\
\hline Central region & 25 & 25 & 25 & 20 & 5 & 0 & \\
\hline Eastern region & 4 & 4 & 32 & 40 & 20 & 0 & \\
\hline \multicolumn{8}{|c|}{ Forage availability in summer rangelands } \\
\hline Western region & 14 & 57 & 29 & 0 & 0 & 0 & \multirow[t]{3}{*}{0.616} \\
\hline Central region & 25 & 65 & 10 & 0 & 0 & 0 & \\
\hline Eastern region & 24 & 64 & 12 & 0 & 0 & 0 & \\
\hline \multicolumn{8}{|c|}{ Forage availability in winter rangelands } \\
\hline Western region & 33 & 57 & 10 & 0 & 0 & 0 & \multirow[t]{3}{*}{0.111} \\
\hline Central region & 35 & 30 & 35 & 0 & 0 & 0 & \\
\hline Eastern region & 36 & 36 & 24 & 4 & 0 & 0 & \\
\hline \multicolumn{8}{|c|}{ Wild-carnivore predation on yaks } \\
\hline Western region & 0 & 5 & 10 & 19 & 67 & 0 & \multirow[t]{3}{*}{0.353} \\
\hline Eastern region $^{\mathrm{A}}$ & 0 & 24 & 36 & 12 & 12 & 8 & \\
\hline Central region & 0 & 10 & 30 & 30 & 25 & 5 & \\
\hline \multicolumn{8}{|c|}{ Access to veterinary health services } \\
\hline Western region ${ }^{\mathrm{B}}$ & 0 & 5 & 19 & 62 & 9 & 0 & \multirow[t]{3}{*}{0.266} \\
\hline Central region & 5 & 5 & 20 & 50 & 20 & 0 & \\
\hline Eastern region ${ }^{\mathrm{B}}$ & 0 & 0 & 16 & 76 & 4 & 0 & \\
\hline \multicolumn{8}{|c|}{ Prevalence of diseases and endoparasite } \\
\hline Western region & 0 & 10 & 19 & 48 & 10 & 14 & \multirow[t]{3}{*}{0.778} \\
\hline Central region & 10 & 40 & 15 & 20 & 0 & 15 & \\
\hline Eastern region & 8 & 24 & 40 & 16 & 0 & 12 & \\
\hline
\end{tabular}

${ }^{\mathrm{A}}$ Rest respondents did not have conflicts with wildlife animals.

${ }^{\mathrm{B}}$ Rest respondents did not have access to veterinary services or yaks were not sick. 